\title{
Palynofacies characterization for hydrocarbon source rock evaluation in the Subathu Formation of Marhighat, Sirmaur district, Himachal Pradesh
}

\author{
O P THAKUR* and N N Dogra \\ Department of Geology, Kurukshetra University, Kurukshetra 136 119, India. \\ *Corresponding author. e-mail: thakurop@gmail.com
}

\begin{abstract}
This paper deals with the hydrocarbon source rock evaluation of the Subathu Formation exposed at Marhighat on Sarahan-Narag road in Sirmaur district of Himachal Pradesh. Hydrocarbon potential of these sediments is estimated on the basis of palynofacies analysis and thermal alteration index (TAI) values based on the fossil spores/pollen colouration. The analyses are based on the classification and hydrocarbon generation potential of plant derived dispersed organic matter present in the sediments. The palynofacies analysis of Subathu Formation in the area reveal moderate to rich organic matter, with amorphous organic matter constituting the bulk of the total organic matter, followed by charcoal, biodegraded organic matter, fungal remains, spores/pollen and structured terrestrial organic matter. The TAI value for the organic matter in these sediments has been ascertained as 3.00. A dominance of the sapropelic facies (amorphous organic matter) and the measured TAI values for the Subathu sediments in the Marhighat area suggests a good source-rock potential for the hydrocarbon generation.
\end{abstract}

\section{Introduction}

The Subathu Formation (Late Palaeocene to Eocene) represents a sequence of coastal, swampy and shallow-to-open marine sediments in Lesser Himalaya. Tectono-stratigraphically, the formation occurs north of the Siwalik Group and overlies unconformably Pre-Tertiary Infra-Krol, Krol Group and Simla slates in different parts of Lesser Himalaya. Lithologically, the Subathu Formation consists of limestones, alternating bands of carbonaceous shales or coal together with limestone bands. In Marhighat area, the upper part of the formation exhibits intercalations of the pale green facies with purple facies. The Subathu Formation in Himachal Pradesh occurs in two distinct tectonic units, viz., the Bilaspur and the Surajpur units (Raiverman and Raman 1971). The geological set-up of the area investigated during the present study is shown in figure 1 (after Kapoor et al 1997). For the palynofacies analysis presented in this paper, rock samples were collected from the Marhighat section exposed near school located $8 \mathrm{~km}$ from Sarahan on Sarahan-Narag road in Sirmaur district of Himachal Pradesh. Litholog of the section investigated during present study is shown in the extreme left of figure 2. As regards the hydrocarbon potential of the Subathu Formation is concerned, a perusal of the published work reveals that the Subathu sediments of Jammu foothills and Himachal Pradesh are characterized by a poor to marginally rich organic carbon content. However, only at few places Subathu sediments are encouraging inorganic carbon content. The present paper embodies the results of palynofacies variation pattern in percentages and thermal alteration index

Keywords. Palynofacies; thermal alteration index; hydrocarbon; source rock; Subathu Formation. 


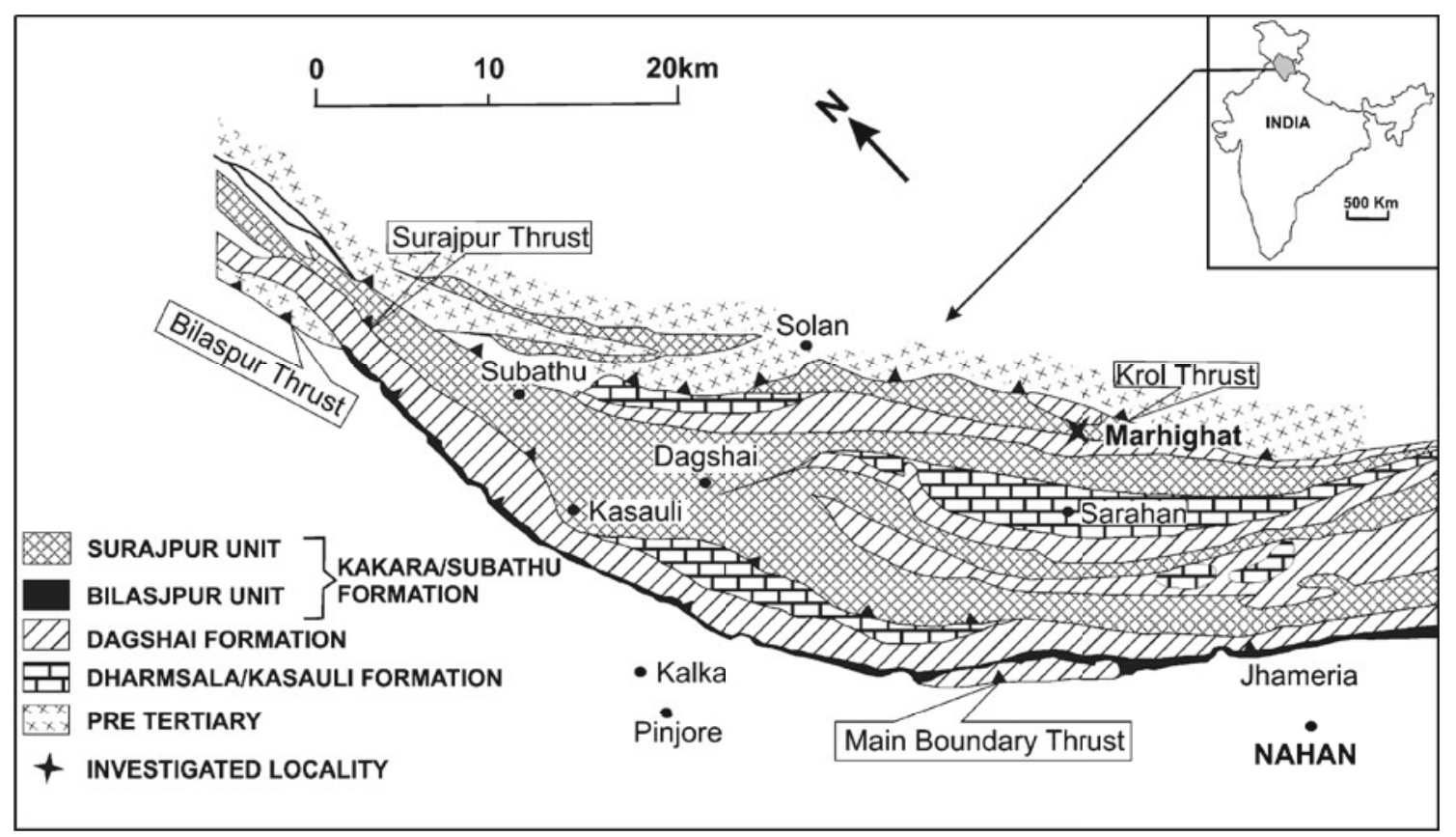

Figure 1. Geological map of Marhighat area, Sirmaur district of Himachal Pradesh (after Kapoor et al 1997).

(TAI) value estimations to evaluate hydrocarbon source rock potential of the Subathu Formation in the area.

Petroleum geologists are well aware of the fact that the dispersed organic matter derived either from marine or non-marine sediments on reaching its maturation level over extended period of time contributes as source material for the production of hydrocarbons. For the study of this dispersed organic matter, many researchers all over the world, have proposed different classifications. The important contributions on such classifications are those of Burgess (1974); Tissot et al (1974); Bujak et al (1977); Masron and Pocock (1981); Venkatachala (1981, 1984); Batten (1983, 1996); Hart (1986); Pocock et al (1987); Tyson (1994) and Boussafir et al (1995). Further, various laboratories engaged in the task of petroleum exploration use their own classification of organic matter. In the present study, the classification of dispersed organic matter proposed by Masron and Pocock (1981) has been adopted with minor modifications. For determining thermal alteration of sediments, many approaches are being used today, most of which require advanced equipments and relatively expensive analytical techniques. We have here applied less costly, relatively simple, effective and globally accepted approach of visually assessing palynomorphs colour to determine TAI (1-5 scale as proposed by Staplin 1969, 1977).

In so far as the detailed palynofacies analysis of Subathu sediments of the area is concerned, much emphasis has not yet been given by the earlier researchers. However, a few sporadic published records on palynofacies and hydrocarbon source rock evaluation studies are of Berry (1989, 1994), Misra and Pundeer (1994) and Berry et al (1998).

Berry (1989) carried out palynofacies and thermal alteration studies on Subathu sediments exposed in Simla Hills from three energy sequences, viz., Dharampur, Kumarhatti and Makreri exposed in Talheri Ki Nadi, Nora Khondal Chakli Khud, Barog Kumarhatti, Koshalia River and KasauliDharampur traverses. A sapropelic organic matter constituted the dominant type in Dharampur and Kumarhatti energy sequence, while Makreri is dominated by humic matter and TAI values $\left(2.5^{-}\right.$ $2.75)$ suggested that the sediments are within the hydrocarbon generation phase.

Berry (1994) carried out palynofacies studies on Subathu-Lower Siwalik subsurface sequences of Nurpur-A and Suruinsar-A wells of Himachal Pradesh and Jammu \& Kashmir areas respectively. The palynofacies maturation studies based on quality, quantity and TAI values suggested that the Lower Dharamsala/Lower Murree and Subathu Formations contained good source potential for hydrocarbons. The Upper Dharamsala/ Upper Murree and Lower Siwalik sediments were evaluated as having poor source potential for hydrocarbons.

Misra and Pundeer (1994) carried out studies on palynofacies and TAI on subsurface sequence encountered in the well Jawalamukhi-B for source rock evaluation of Subathu to Middle Siwalik 


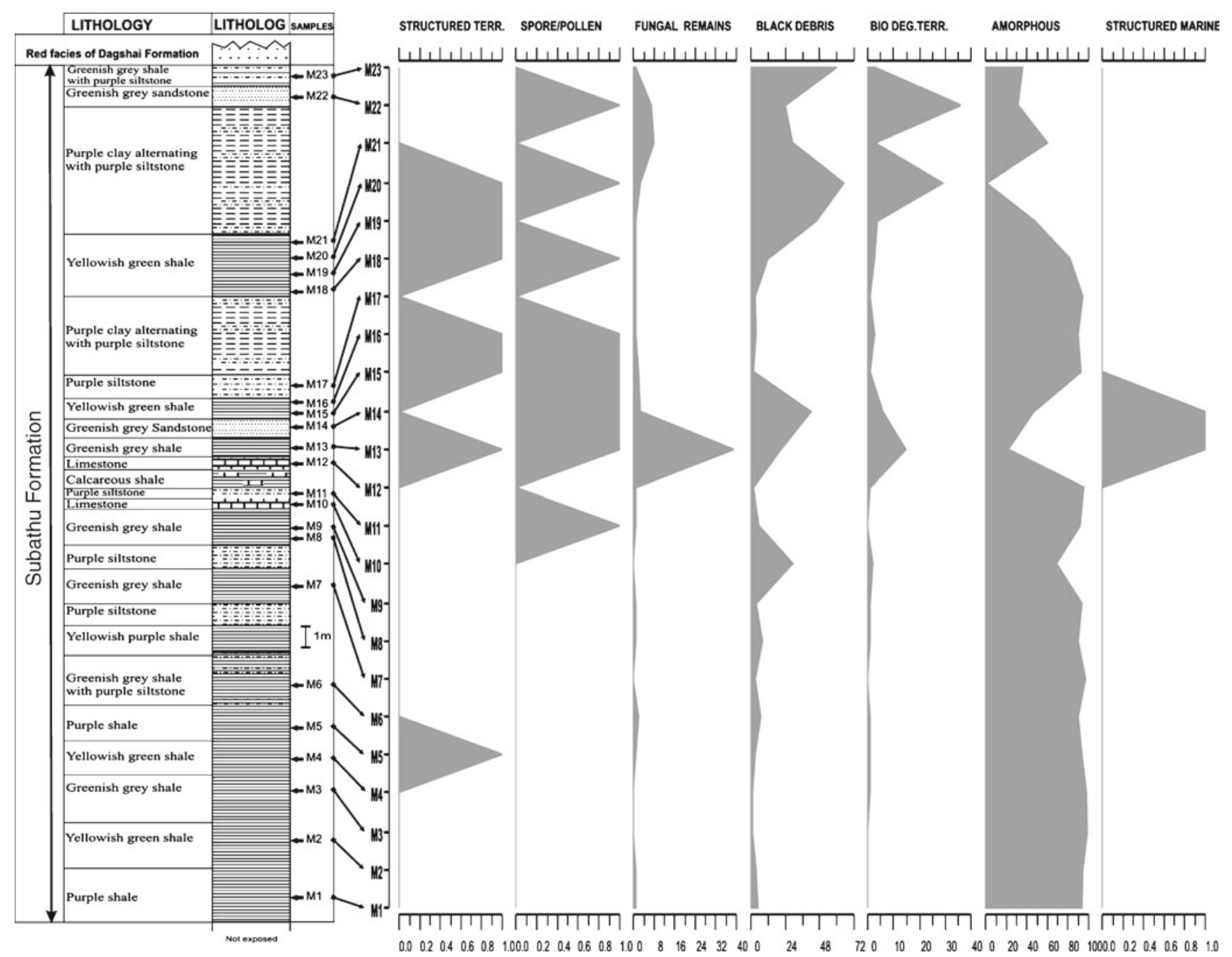

Figure 2. Distribution of dispersed organic matter in Marhighat section of Subathu Formation exposed at Marhighat, Sirmaur district, H.P., India.

sediments. They have recorded 12 humic, sapropelic and mixed facies zones in the sequence. Biodegraded organic matter had been the dominant organic matter followed by charcoal, amorphous organic matter and wood/cuticle. TAI (2.75-3) values and the type of organic matter recorded between 6727 and $5298 \mathrm{~m}$ depth suggested very good source potential for Palaeocene to Lower Eocene sediments (Subathu-Lower Dharamsala?). TAI of 2.5-2.75 was recorded between 928 and $5298 \mathrm{~m}$ in Middle Eocene to Middle Miocene (Lower Dharamsala-Lower Siwalik) rocks. Middle Siwalik sediments were rated immature for generation of hydrocarbons.

Berry et al (1998) also carried out the studies for hydrocarbon potential of Subathu sediments along Batalghat-Bhararighat and Samog-Malhoti traverses in the Bilaspur district of Himachal Pradesh. The total organic matter they recorded was poor to moderate, however few samples contained good concentration of organic matter. This organic matter is dominated of amorphous organic matter followed by biodegraded organic matter with TAI value as 3.00. The facies recorded from these traverses are sapropelic-inertinitic and the sourcerock potential for hydrocarbon is moderate type.

\section{Methodology}

The hydrocarbon source rock potential of the Subathu Formation of Marhighat area is evaluated on the basis of dispersed organic matter and TAI. The dispersed organic matter in the rock samples is isolated by standard maceration technique (Faegri and Iversen 1989), which involves digestion with hydrochloric acid and hydrofluoric acid. The nitric acid treatment is avoided to get unoxidised residue. The macerate is thoroughly washed and smeared on zero cover glass and mounted on slides using polyvinyl alcohol and Canada-balsam. The quantitative estimation of the organic matter 
is made by visual estimation and the classification described by Masron and Pocock (1981) is adopted here. TAI values are assessed on the $1-5$ scale of Staplin $(1969,1977)$.

\section{Hydrocarbon source rock evaluation}

Sediments that have been able to generate petroleum or which may have the potential to do so are called 'source rocks'. Organic rich shales, mudstones and certain very fine-grained carbonates deposited under suitable conditions and oxygen deficient waters are considered excellent source sediments. Both autochthonous and allochthonous organic debris contribute to the total organic matter (TOM) of a litho-unit. Type of organic matter and its facies are considered very important while evaluating source rock potential. These types of organic matter must be identified and distinguished, for different types of organic matter have different hydrocarbon potentials and products. The dispersed organic matter is classified in to various categories depending on the degree of alteration (Masron and Pocock 1981) as shown in table 1.

The different types of organic matter identified in the investigated sedimentary sequence of the Marhighat area are broadly classified into: humic and sapropelic. The humic organic matter is land

Table 1. Classification of the particulate organic matter in the sediments (after Masron and Pocock 1981).

\begin{tabular}{ll}
\hline Categories & Sub-categories \\
\hline Sructured terrestrial & Leaf \\
organic matter & Root \\
(Telinite) & Stem \\
Spores and pollen & \\
(Sporonite) & \\
Biodegraded terrestrial & Stem and root \\
organic matter & Sheets of cells with wall \\
(Telocollinite) & Sheets of cells lacking walls \\
Charcoal/black debris & Degrado-charcoal \\
(Fusinite) & (Degradofusinite) \\
& Pyrocharcoal \\
Fungi (Sclerotinite) & (Pyrofusinite) \\
& Mycelia \\
Amorphous organic & Single celled spores \\
matter & Multicelled spores \\
Structured aqueous & Yellow \\
organic matter & Grey \\
& Algal \\
& Dinoflagellates \\
& Achritarchs \\
& Other \\
\hline
\end{tabular}

Terms within brackets are the equivalent coal maceral categories. or terrestrially derived and is easily recognizable, however, sapropelic organic matter is derived both from marine and terrestrial sources. These broad organic matter types are further subdivided and classified in to subfacies (based on Swamy et al 1994) to evaluate hydrocarbon source rock potential of these sediments. The different types of organic matter and their frequency variation patterns as revealed in the Marhighat section of the Subathu Formation is depicted in figure 2 and the hydrocarbon source rock potential based on the type of each of the recovered organic matter subfacies and TAI is discussed as below.

- Structured terrestrial (wood/cuticle): This organic matter comprises unaltered cellular remains of leaf, root and stem tissues and is represented in low frequency, i.e., 0-1\% (avg. $0.3 \%$ ) in the study area. It mainly contributes for gaseous hydrocarbons.

- Biodegraded organic matter: This is the plant derived organic matter that has undergone a considerable amount of biodegradation, but still shows visual traces of its cellular structure. The frequency of biodegraded organic matter in the investigated area is $0-36 \%$ (avg. 4.9\%). This organic matter is considered to possess enhanced hydrocarbon source potential than structured terrestrial organic matter.

- Amorphous organic matter: This organic matter is completely structureless and is the end product of structured and biodegraded plant parts. Amorphous organic matter in the present section is of yellowish to grey in colour which indicates the presence of reducing environmental conditions during deposition (Masron and Pocock 1981). The frequency of this organic matter is quite high (avg. 75\%) in the studied sediments and the range varies from 1-99\%. Amorphous organic matter is considered to be an excellent source for liquid hydrocarbons.

- Black debris/charcoal: This is the product of oxidation of structured materials. Occurrence of black debris in the above sediments ranges between 1 and $65 \%$ (avg. 16.6\%). Black debris suggests oxidizing environment during deposition. It has no/negligible hydrocarbon source rock potential except for dry gas.

- Spores/pollen: Spores and pollen are known to be rich in lipids, which contribute mostly to liquid hydrocarbons. The frequency of spores and pollen is quite low $(<1 \%)$ in the studied sediments.

- Fungal remains: The frequency of fungal remains in the sediments ranges from 0-39\% (avg. 3.3\%). Fungal remains are the major agents of biodegradation of organic matter eventually converting it to an amorphous mass. They are 
rich in proteins and lipids and could be a moderately good source of hydrocarbons.

- Structured marine (phytoplankton): Structured marine organic matter in the sediments is mainly contributed by dinoflagellates and its frequency ranges from $0-1 \%$ (avg. $0.1 \%$ ).

The overall dominance/trend of different types of organic matter in the Marhighat section is:

Amorphous organic matter $>$ black debris $>$ biodegraded terrestrial organic matter $>$ fungal remains $>$ spores/pollen $>$ structured terrestrial organic matter $>$ structured marine (phytoplankton). The dominance of amorphous organic matter and biodegraded terrestrial organic matter in the Subathu Formation of the area indicates good source-rock potential for hydrocarbons.

The distribution of dispersed organic matter (figure 2) clearly reveals that the lower and middle parts of the Marhighat section are dominated by amorphous organic matter whereas, the upper part of the section is dominant in black debris (charcoal) facies. The lower and middle parts of the succession, therefore, can be categorized as sapropelic organic matter facies with adequate maturity (TAI $3.0)$ to generate liquid hydrocarbons, while the upper part of the succession has sapropelic humiccharcoal facies with TAI 3.0, which is considered to be moderate to good for gaseous hydrocarbon generation.

\subsection{Thermal alteration index (TAI)}

For evaluating organic maturation level of the sediments vis-a-vis hydrocarbon potential, TAI to the $1-5$ scale as proposed by Staplin $(1969,1977)$; has been used for the present study. The TAI is based upon the maturation colour of spores-pollen, cuticles and phytoplankton. Also the humic and amorphous-sapropelic matters were used in the present study for determining TAI values in the absence of palynomorphs. The TAI values worked out for the Subathu sediments of area are measured as 3.0, which is an optimum maturation level of a very good hydrocarbon source rock potential.

\section{Conclusions}

The occurrence and relative abundance of dispersed organic matter types, the thermal maturation levels as evaluated by TAI values and the dominance of organic facies have been worked out to interpret the hydrocarbon source potential of the Subathu Formation of Marhighat area. The palynofacies data generated during the analysis is quite significant in understanding hydrocarbon generation potential of these sediments. The present study reveals a moderate to fairly rich organic matter in the sequence. The lower and middle part of the Marhighat succession is dominant in amorphous organic matter whereas the upper part is dominant in black debris (charcoal). TAI values of these sediments are measured as 3.0, which indicate well-matured facies. The lower and middle part of the sequence has sapropelic organic matter facies with adequate maturity (TAI 3.0) to generate liquid hydrocarbons, while the upper part of the sequence has sapropelic humic-charcoal facies with TAI 3.0, which is considered to be moderate to good for gaseous hydrocarbon generation.

\section{Acknowledgements}

The first author $\mathrm{O} \mathrm{P}$ Thakur is grateful to Dr N C Mehrotra, Director, Birbal Sahni Institute of Palaeobotany for providing the necessary research facilities and permission to publish the paper. Authors are also thankful to Chairman, Department of Geology, Kurukshetra University, Kurukshetra for providing research facilities. Authors thankfully acknowledge anonymous referees for their suggestions in improving the quality of research paper.

\section{References}

Batten D J 1983 Identification of amorphous sedimentary organic matter by transmitted light microscopy; In: Petroleum geochemistry and exploration of Europe (ed.) Brooks J, Blackwell Scientific Publications: Boston, Geol. Soc. Spec. Publ. 12 275-287.

Batten D J 1996 Palynofacies and palaeoenvironmental interpretation; In: Palynology: Principles and applications (eds) Jansonius J and McGregor D C, Amer. Assoc. Strat. Palynol. 3 1011-1064.

Berry C M 1989 Source rock palynology of Subathu sediments of Simla Hills; Geophytology 19 140-146.

Berry C M 1994 Hydrocarbon potential of Siwalik and Pre-Siwalik sediments in Himachal Pradesh and JammuKashmir areas - A palynological perspective; Him. Geol. 15 321-328.

Berry C M, Pundeer B S and Mukherjee B K 1998 Hydrocarbon potential of Subathu sediments in Jammu-Kashmir, Himachal Pradesh and Uttar Pradesh - A palynological perspective; Bull. ONGC 35 1-16.

Boussafir M F, Gelin E, Lallier-Verges S, Derenne P, Bertrand and Largeau C 1995 Electron microscopy and pyrolysis of kerogens from the Kimmeridge Clay Formation, UK: Source organisms, preservation processes, and origin of microcycles; Geochim. Cosmochim. Acta $\mathbf{5 9}$ 3731-3747.

Bujak J P, Barss M S and Williams G L 1977 Offshore east Canada's organic type and color and hydrocarbon potential, part I; Oil and Gas Journal 75 198-202.

Burgess J D 1974 Microscopic examination of kerogen (dispersed organic matter) in petroleum exploration; In: Carbonaceous materials as indicators of metamorphism 
(eds) Dutcher R R, Hacquebard P A, Schopf J M and Simon J A, GSA Special Paper 153 19-30.

Faegri K and Iversen J 1989 Textbook of Pollen Analysis; (New York: Wiley), pp. 1-328.

Hart G F 1986 Origin and classification of organic matter in clastic systems; Palynology 10 1-23.

Kapoor R, Singh R Y and Dogra N N 1997 Palynological assemblage from the Subathu Formation, Kalka-Kasauli road: Aspects and appraisal; Bull. Ind. Geol. Assoc. 30 $31-37$.

Masron Th C and Pocock S A J 1981 The classification of plant-derived particulate organic matter in sedimentary rocks; In: Organic maturation studies and fossil fuel exploration (ed.) Brooks J (London: Academic Press), pp. $145-161$.

Misra C M and Pundeer B S 1994 Palynofacies, maturation and source rock potential in the well Jawalamukhi-B, Himalayan foothills; In: Proc. Second Seminar on Petroliferous Basins of India (eds) Biswas S K et al (Dehradun, India: Indian Petroleum Publishers) 3 161-171.

Pocock S A J, Vasanthy G and Venkatachala B S 1987 Introduction to the study of particulate organic materials and ecological perspectives; J. Palynol. 23-24 167-188.
Raiverman V and Raman K S 1971 Facies relation in the Subathu sediments, Simla Hills, Northwestern Himalaya; Geol. Surv. India Misc. Publ. 41 11-126.

Staplin F L 1969 Sedimentary organic matter, organic metamorphism and oil and gas occurrence; Bull. Canadian Petrol. Geol. 17 47-66.

Staplin F L 1977 Interpretation of thermal history from colour of particulate organic matter - A review; Palynology 1 9-18.

Swamy S N, Misra C M and Kapoor P N 1994 Novel strategy in source rock palynological techniques for hydrocarbon exploration; Geosci. J. 15.

Tissot B, Durand B, Espitalie J and Combaz A 1974 Influence of nature and diagenesis of organic matter in formation of petroleum; AAPG Bull. 58 499-506.

Tyson R V 1994 Sedimentary organic matter: Organic facies and palynofacies (New York: Chapman and Hall) pp. 1-615.

Venkatachala B S 1981 Hydrocarbon source rock evaluation A new palynological approach; Petrol. Asia J. 4 80-93.

Venkatachala B S 1984 Finely divided organic matter, its origin and significance as a hydrocarbon source material; Bull. ONGC $2123-45$. 